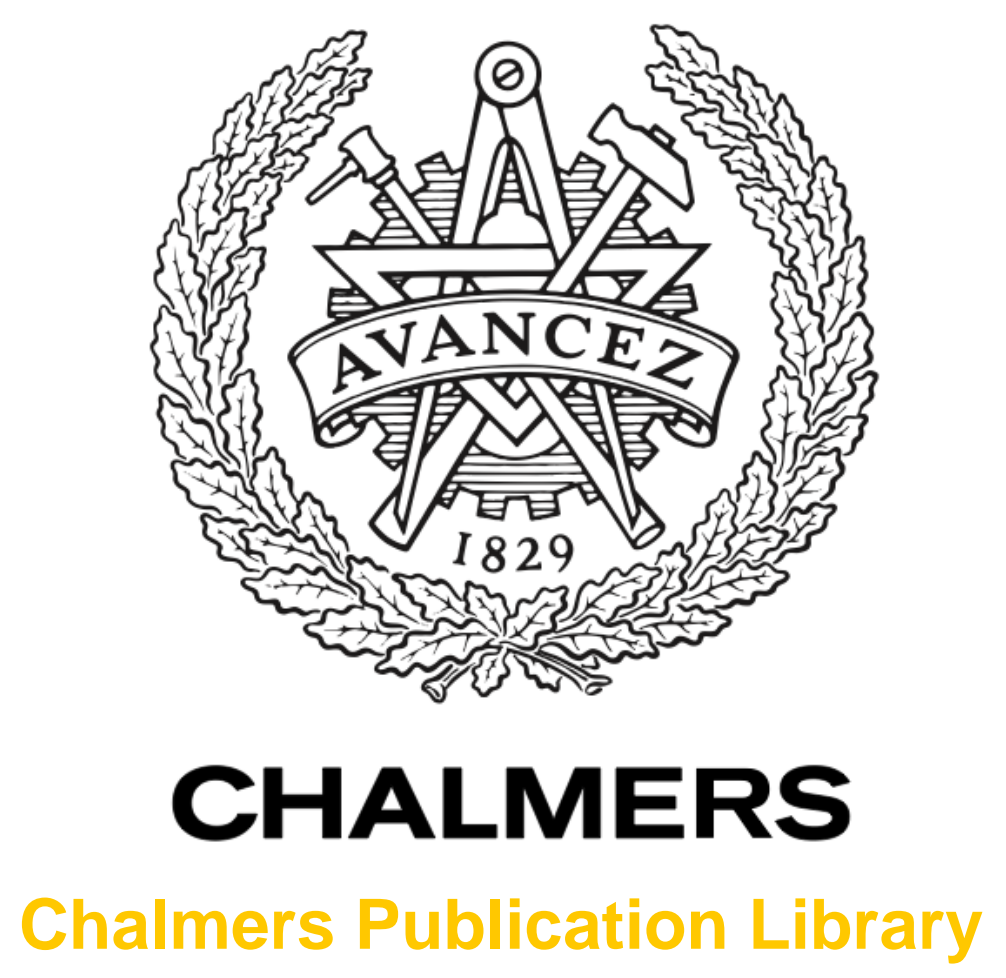

Motives to adopt renewable electricity technologies: Evidence from Sweden

This document has been downloaded from Chalmers Publication Library (CPL). It is the author's version of a work that was accepted for publication in:

Energy Policy (ISSN: 0301-4215)

Citation for the published paper:

Bergek, A. ; Mignon, I. (2017) "Motives to adopt renewable electricity technologies:

Evidence from Sweden". Energy Policy, vol. 106 pp. 547-559.

http://dx.doi.org/10.1016/j.enpol.2017.04.016

Downloaded from: http://publications.lib.chalmers.se/publication/248862

Notice: Changes introduced as a result of publishing processes such as copy-editing and formatting may not be reflected in this document. For a definitive version of this work, please refer to the published source. Please note that access to the published version might require a subscription. 


\title{
Motives to adopt renewable electricity technologies: evidence from Sweden
}

\author{
Anna Bergek ${ }^{\mathrm{a}, \mathrm{b}, *}$ \& Ingrid Mignon ${ }^{\mathrm{a}}$ \\ ${ }^{a}$ Department of Management and Engineering, Linköping University, SE-58I 83 Linköping, Sweden. \\ ${ }^{b}$ Department of Energy and Environment, Chalmers University of Technology, SE-4 I 296 Göteborg, \\ Sweden.
}

Email: Email: anna.bergek@chalmers.se, ingrid.mignon@liu.se

\section{*Corresponding author}

This is a post print version. Please refer to the published article:

Bergek, A., Mignon, I., 2017. Motives to adopt renewable electricity technologies: evidence from Sweden, Energy Policy, 106: 547-559 (http://doi.org/10.1016/i.enpol.2017.04.016).

(C) 2017. This manuscript version is made available under the CC-BY-NC-ND 4.0

license http://creativecommons.org/licenses/by-nc-nd/4.0/

\begin{abstract}
The diffusion of renewable electricity technologies (RETs) has to speed up for countries to reach their, often ambitious, targets for renewable energy generation. This requires a large number of actors - including individuals, companies and other organizations - to adopt RETs. Policies will most likely be needed to induce adoption, but there is limited knowledge about what motivates RET adoption. The purpose of this paper is to complement and expand the available empirical evidence regarding motives to adopt RETs through a survey to over 600 RET adopters in Sweden. The main finding of the study is that there are many different motives to adopt RETs and that RET adopters are a heterogeneous group with regard to motives. Although environmental concerns, interest in the technology, access to an RE resource and prospects to generate economic revenues are important motives in general, adopters differ with regard to how large importance they attach to the same motive and each adopter can also have several different motives to adopt. There are also differences in motives between adopter categories (especially independent power producers vs. individuals and diversified companies) and between RETs (especially wind power vs. solar power). This implies that a variety of policy instruments might be needed to induce further adoption of a variety of RETs by a variety of adopter categories.
\end{abstract}

Keywords: renewable energy, motive, adoption, diffusion, investment 


\section{Introduction}

In recent years, many countries have implemented measures to reduce the use of fossilbased energy generation, including various policies to stimulate the deployment of technologies for renewable electricity generation (RETs). As a consequence (at least in part) of such policies, the rate of diffusion of RETs and the installed renewable electricity generation capacity has increased rapidly, but many countries are still far from reaching the ambitious targets set in, e.g., the EU climate and energy package (Eurostat, 2015b; Jacobsson and Bergek, 2011). This implies that further diffusion is needed in the coming years.

Yet, governments cannot undertake the required investments alone (Wüstenhagen and Menichetti, 2012). Indeed, for RETs (or any innovation) to spread, a large number of different actors both have to decide to adopt it and implement their adoption decisions successfully (Linton, 2002; Mignon, 2016). Despite the association of the term "diffusion" with the exchange of gases or transfer of diseases, innovation diffusion is, thus, not a seamless process, but instead built up by a micro-foundation of many singular, and often quite complex, adoption processes by individuals or organizations (Rogers, 1983). These processes are influenced by a large set of economic, behavioural, organizational and structural factors, both at the supply and the demand side (Tidd, 2010). Among these factors, this paper focuses on adoption motives. ${ }^{1}$

\footnotetext{
${ }^{1}$ It should be noted that motives are not necessarily the same thing as motivations. A motive is a reason for doing something specific (in this case investing in a particular RET at a particular time), whereas motivation is the reason for a particular, but more general, pattern of action or behavior (e.g. always choosing the most environmentally friendly alternative when buying something). In the literature, these two concepts are used interchangeably, but we have opted to use the term 'motive' since we are interested specifically in the first of these two meanings.
} 
Motives are important because an adoption decision will not be made unless the individual adopter has some kind of reason or incentive to adopt (Jensen, 1982). Previous literature also suggests that motives influence how adopters react to different investment contexts (e.g. commercial conditions) (Bauwens, 2016; Dinica, 2006), what types of technologies they choose to invest in (Lillemo et al., 2013; Michelsen and Madlener, 2013) and what business models they choose (Barradale, 2010). Motives are, thus, highly relevant for policy makers: If policy makers want to strengthen the incentives to adopt certain technologies, they need to understand what motivates adoption of these technologies and how adopters with different motives are likely to react to particular policies (Bergek et al., 2013; Mignon and Bergek, 2016).

RETs are often framed as environmental innovations, which might signal the importance of environmental motives. However, as discussed by Stern (2000), environmental behaviour can also originate in non-environmental concerns. In line with this, much of the energy literature assumes that RET adoption is primarily motivated by economically rational profitability considerations (Michelsen and Madlener, 2013). This is, for example, evident in studies that compare investments in RETs with other energy investments based on the assessment criteria used by utilities and energy planners (cf. Awerbuch, 2000, 2003; Bhattacharya and Kojima, 2012). This also seems to be the assumption made by policy makers, considering the dominance of various forms of economic incentives for RET adoption (Mignon and Bergek, 2016; Schelly, 2014). There is, however, little previous research on RET adoption from the point of view of adopters (Vasseur and Kemp, 2015). A particular concern is that while the abovementioned assumptions are derived from knowledge about the investment behaviour of traditional adopters, such as utilities and energy companies, previous 
studies have shown that the primary drivers of the RET diffusion process are nontraditional RET adopters, such as households, cooperatives, diversifying firms and other organizations (Bergek et al., 2013). Most of the empirical studies of such adopters focus on identifying factors that influence RET adoption at an aggregated level. These factors include, for example, innovation characteristics (e.g. relative advantage and ease of use), adopter characteristics (e.g. income, status and age) or external influences (e.g. government policies) (cf. e.g. Arkesteijn and Oerlemans, 2005; Balcombe et al., 2014; Karakaya et al., 2015; Michelsen and Madlener, 2013; Schelly, 2014; Tate et al., 2012; Walekhwa et al., 2009; Vasseur and Kemp, 2015). Only a few of these studies also look into the question of why non-traditional adopters decide to adopt RETs, and there is little agreement about the relative importance of different motives for RET adoption (Balcombe et al., 2013; Bauwens, 2016). Moreover, most of the available studies of motives of non-traditional adopters are focused on the adoption of solar PV cells by households (see Section 2). Adopters of RE are, however, a heterogeneous group. It does not only consist of households, but also of various types of companies and organizations, and it adopts other RETs than solar PV (e.g. wind power, bioenergy and hydro power technologies) (Bergek et al., 2013; trend:research, 2013). Considering that there are some indications that motives differ between adopter types and RETs (cf., e.g., Caird et al., 2008; Sidiras and Koukios, 2004), more research is needed to confirm (or complement) the insights gained so far.

Against this background, the purpose of this paper is to complement and expand the available empirical evidence regarding motives to adopt RETs by (1) identifying motives for RET adoption in Sweden and (2) investigating the relative importance of different 
motives, both for the entire population of non-traditional adopters and for different adopter categories and RETs.

\section{Motives to adopt RETs: previous literature and remaining gaps}

In this section, we will first review and summarize the findings from a number of previous empirical studies of RET adoption motives from the perspective of nontraditional adopters (see Table 1 ). ${ }^{2}$ Based on this review, we will then discuss the current status of knowledge and understanding of motives to adopt RETs in order to identify unresolved issues and formulate our own research questions.

\section{I Adoption motives identified in previous studies}

At a general level, motives to adopt sustainable innovations, such as RETs, can be divided into three categories: instrumental motives reflect the functional outcome of ownership and use, i.e. the direct benefits of the technology for the owner/user, environmental motives reflect the contribution of ownership and use for the environment and symbolic motives reflect the outcomes of the ownership and use for the adopter's identity and social status (cf. Noppers et al., 2014). We will use this overall categorization as a structure for our review of previous studies on motives to adopt RETs.

\footnotetext{
2 Two things should be noted here. (1) As mentioned in the introduction, there is also a literature that discusses adoption of RETs by utilities and energy planners (for a review, see Bergek et al. (2013)). However, this literature does not concern itself much with investigating the motives behind such investments. Instead, it is focused on the criteria these companies use (or should use) to decide what specific technology to adopt once an adoption decision has been made. (2) We focus on studies of the motives of those who have actually adopted RETs. Studies of mere intentions, attitudes or considerations to adopt have therefore been excluded (see Balcombe et al. (2013) and Korcaj et al. (2015) for reviews of such studies with regard to microgeneration technologies and solar PV systems respectively).
} 
Table 1. Overview of studies of motives to adopt renewable electricity generation technologies.

\begin{tabular}{|c|c|c|c|c|}
\hline & RET & $\begin{array}{l}\text { Adopter } \\
\text { category }\end{array}$ & Country & Sample size \\
\hline $\begin{array}{l}\text { Balcombe et } \\
\text { al. (2014) }\end{array}$ & $\begin{array}{l}\text { Microgeneration (solar PV, solar } \\
\text { thermal, micro-wind turbines, } \\
\text { heat pumps, biomass, micro-CHP } \\
\text { and micro-hydro) }\end{array}$ & Consumers & UK & $\begin{array}{l}\text { Survey (113 } \\
\text { adopter- } \\
\text { respondents) }\end{array}$ \\
\hline $\begin{array}{l}\text { Caird et } \\
\text { al.(2008) }\end{array}$ & $\begin{array}{l}\text { Various (wood burning stoves, } \\
\text { solar thermal systems, solar PV } \\
\text { systems and micro-wind } \\
\text { turbines) }\end{array}$ & Households & UK & $\begin{array}{l}\text { Survey (121 } \\
\text { adopter- } \\
\text { respondents) }\end{array}$ \\
\hline $\begin{array}{l}\text { Fischer } \\
(2008)\end{array}$ & $\begin{array}{l}\text { Micro fuel cell CHP (applications } \\
\text { for a field test) }\end{array}$ & $\begin{array}{l}\text { Households } \\
\text { (mainly) }\end{array}$ & Germany & $\begin{array}{l}\text { Survey }(142 \\
\text { applicant- } \\
\text { respondents) }\end{array}$ \\
\hline $\begin{array}{l}\text { Mbzibain et } \\
\text { al. }(2013)^{a}\end{array}$ & $\begin{array}{l}\text { Various (e.g. solar PV systems, } \\
\text { biomass boilers, wind turbines } \\
\text { and CHP) }\end{array}$ & Farmers & UK & $\begin{array}{l}\text { Survey (55 } \\
\text { adopter- } \\
\text { respondents) }\end{array}$ \\
\hline $\begin{array}{l}\text { Nygrén et al. } \\
\text { (2015) }\end{array}$ & $\begin{array}{l}\text { Various (solar PV systems, } \\
\text { micro-wind turbines, heat } \\
\text { pumps, production and } \\
\text { consumption of biogas, biodiesel } \\
\text { and wood energy). }\end{array}$ & Households & Finland & $\begin{array}{l}\text { Interviews } \\
\text { ( } 54 \text { adopter- } \\
\text { interviewees) }\end{array}$ \\
\hline $\begin{array}{l}\text { Palm and } \\
\text { Tengvard } \\
\text { (2011) }\end{array}$ & $\begin{array}{l}\text { Grid-connected solar PV systems } \\
\text { and micro-wind turbines }\end{array}$ & Households & Sweden & $\begin{array}{l}\text { Interviews } \\
\text { ( } 20 \text { adopter- } \\
\text { interviewees) }\end{array}$ \\
\hline $\begin{array}{l}\text { Schelly } \\
(2014)\end{array}$ & Solar PV systems & Households & $\begin{array}{l}\text { USA } \\
\text { (Wisconsin). }\end{array}$ & $\begin{array}{l}\text { Interviews } \\
\text { ( } 48 \text { adopter- } \\
\text { interviewees } \\
\text { ( } 36 \text { cases of } \\
\text { adoption)) }\end{array}$ \\
\hline $\begin{array}{l}\text { Tate et al. } \\
(2012)^{\mathrm{a}}\end{array}$ & $\begin{array}{l}\text { Various (e.g. solar PV systems, } \\
\text { biomass boilers, wind turbines, } \\
\text { and CHP) }\end{array}$ & Farmers & UK & $\begin{array}{l}\text { Survey (55 } \\
\text { adopter- } \\
\text { respondents) }\end{array}$ \\
\hline $\begin{array}{l}\text { Vasseur and } \\
\text { Kemp } \\
(2015)\end{array}$ & Solar PV systems & Households & $\begin{array}{l}\text { The } \\
\text { Netherlands }\end{array}$ & $\begin{array}{l}\text { Survey (38 } \\
\text { adopter- } \\
\text { respondents) }\end{array}$ \\
\hline $\begin{array}{l}\text { Warren } \\
(2010)\end{array}$ & Microgeneration technologies & SMEs & UK & $\begin{array}{l}\text { Interviews } \\
(17 \text { SMEs, but } \\
\text { unclear if all } \\
\text { were } \\
\text { adopters) }\end{array}$ \\
\hline
\end{tabular}

a Tate et al. (2012) and Mbzibain et al. (2013) are based on the same empirical study.

\subsubsection{Instrumental motives}

Instrumental motives are related to the concrete benefits an adopter sees in investing in an innovation with regard to its functional use (in relation to the investment cost). This is not a fixed "relative advantage" characteristic of the new technology in relation to 
available substitutes (as suggested by the traditional innovation diffusion literature (cf. Rogers, 1983)), but a valuation made by each potential adopter (Vasseur and Kemp, 2015). Economic motives are traditionally seen as key here; not only is it acknowledged in the innovation diffusion literature that the relative price-performance ratio is an important factor in decisions to adopt any new technology (Rogers, 1983), but the traditional energy economics literature also tends to assume that investments in energy production technologies are based on strict evaluations of plant profitability and return on investment (for an overview, see Bergek et al., 2013).

However, the available empirical evidence suggests that the economic motives related to RET adoption differ somewhat from these general assumptions. Although some studies show that some adopters hope to generate economic revenues (sometimes related to the availability of economic policy incentives) (cf. Balcombe et al., 2014; Mbzibain et al., 2013; Palm and Tengvard, 2011; Schelly, 2014), most of them are motivated by the longterm possibilities to reduce their energy bills or avoid other costs (Balcombe et al., 2014; Caird et al., 2008; Fischer, 2008; Mbzibain et al., 2013; Nygrén et al., 2015; Warren, 2010; Vasseur and Kemp, 2015). This is in some cases related to expectations of increasing price levels rather than to current investment profitability. For example, Balcombe et al. (2014) found that some households in the UK adopted microgeneration technologies, such as solar PV systems, to protect themselves against future price rises (cf. also Nygrén et al., 2015; Palm and Tengvard, 2011).

Moreover, even when more traditional return on investment motives are in place, the relative profitability of RETs in comparison with other energy sources seems to be less important than the opportunity for diversification they offer. For example, Mbzibain et al. (2013) found that many farmers in the West Midland Region of the UK adopted RETs 
to diversify farm incomes and take advantage of market opportunities and Tate et al. (2012) showed that these farmers actually perceived RE production as a better business than their current agricultural business. In such cases, RET investments are, thus, compared with alternative investments in other sectors than energy.

Finally, some households adopt RETs not because of economic revenues or cost reductions, but because they want to exploit resources readily available to them. For example, Nygrén et al. (2015) found that some Finnish households adopted RETs to improve energy and material efficiency, Palm and Tengvard (2011) found that some Swedish households adopted solar PV systems because they wanted to make use of the natural resources available to them in their close environment and Schelly (2014) found that some of the Wisconsin households that adopted PV solar systems did so because they had recently inherited some money or because they wanted to transfer some of their own money to their children as an advance payment on future inheritances.

In addition, previous studies of RET adoption highlight a number of non-economic instrumental motives. First, people and companies adopt RETs to become self-sufficient energy producers and, thus, independent of the central electricity grid or of large utilities (Balcombe et al., 2014; Nygrén et al., 2015; Palm and Tengvard, 2011; Vasseur and Kemp, 2015). ${ }^{3}$ In some cases, this strive for self-sufficiency seems to be related to a perceived need to protect oneself against power shortages and blackouts (Balcombe et al., 2014).

\footnotetext{
${ }^{3}$ If this motive was based on an ideological standpoint (e.g. against centralization or similar), it could be categorized as symbolic rather than instrumental. However, in several of the studies it is described more as a general positive feature of the technology as such.
} 
Second, some adopters have an interest in the technology as such (Fischer, 2008; Nygrén et al., 2015; Palm and Tengvard, 2011). For example, some of the households that adopted solar PV systems and other micro-generation technologies in Sweden, the UK and the US were motivated by the functioning of the power plant itself, including the challenge of adopting an innovative technology (Balcombe et al., 2014; Schelly, 2014).

Third, in some cases the motive to adopt RETs is a need to solve a practical problem of some kind. For example, some adopters of renewable heating technologies in Norway invested to replace or modernize their existing appliances or equipment (Schelly, 2014) and some adopters of RETs and micro-generation technologies in Finland and the UK invested to get rid of some kind of waste (e.g. manure or excess wood), which could be used as an input to renewable energy production (Mbzibain et al., 2013; Nygrén et al., 2015).

\subsubsection{Environmental motives}

Environmental motives are those that concern the perceived positive impact of adoption decisions on the environment. In the literature on sustainable innovations, it has been suggested that the adoption of such innovations is likely to be motivated by the fact that they are more environmentally friendly than the technologies they aim to replace (Noppers et al., 2014).

This also seems to be the case for RET adoption. In all of the reviewed studies, a large group of people and companies adopted RETs at least in part because they were concerned about the environment and the rights of coming generations and therefore wanted to reduce their own environmental impact by saving energy or producing clean energy (Balcombe et al., 2014; Caird et al., 2008; Fischer, 2008; Nygrén et al., 2015; Palm and Tengvard, 2011; Warren, 2010; Vasseur and Kemp, 2015). More specifically, 
households and companies adopted RETs to reduce greenhouse gas emissions (Mbzibain et al., 2013; Schelly, 2014) and improve local air quality (Mbzibain et al., 2013). Some also adopted to promote the development of RETs as such (Nygrén et al., 2015).

However, in one study there were also some adopters who were very much against "environmentalism" and who emphasized that their motives were altogether different (cf. Schelly, 2014).

\subsubsection{Symbolic motives}

Symbolic motives signal the status or identity of the adopter (Noppers et al., 2014). They are closely related to the normative motivations described by Lindenberg and Steg (2007), which are based on a desire to act in certain ways in order to meet the expectations of their community (or themselves).

In previous studies of RET adoption, a number of symbolic motives have been identified. Most notably, some people seem to adopt RETs because they want to improve their own image or reputation by showing their neighbours or other people that they are concerned about the environment (Balcombe et al., 2014; Caird et al., 2008; Dinica, 2006; Noppers et al., 2014; Nygrén et al., 2015; Palm and Tengvard, 2011). For example, some household adopters of solar PV systems in Sweden and the UK installed them to show that they were "green" (Caird et al., 2008) or to signal that it is possible to make a difference (Palm and Tengvard, 2011).

Similarly, some companies invest in RETs to use them as a marketing argument to sell more of their main products. For example, a study of SMEs in the UK highlighted the 
importance of "green marketing" as a motive to adopt various kinds of micro-generation technologies (Warren, 2010).

Finally, some adopt to conform to government policies even when this is not related to a direct, instrumental benefit for them. For example, Warren (2010) found that a fair share of the SMEs that adopted micro-generation technologies in the UK did so because of political targets. Likewise, according to Mbzibain et al. (2013) at least some of the farmers that adopted RE enterprises in the UK reported that helping the government meet its climate and energy targets was one of their top four adoption motives.

\subsection{Summary, discussion and research questions}

The previous section shows that there is at least some knowledge of motives to adopt RETs. The reviewed studies confirm that there are different types of motives for RET adoption (economic and non-economic instrumental motives, environmental motives and symbolic motives) and provide examples of different motives within each type. However, this literature is still quite new and several issues are, therefore, still unresolved.

First, the relative importance of different motives is not very well understood. Adopters can have several different reasons for behaving in certain ways (cf. Stern, 2000) and this applies both to environmental behaviour in general and to the adoption of RETs specifically (Balcombe et al., 2014; Fischer, 2008; Noppers et al., 2014; Stern, 2000). Only some of the studies reviewed above have explicitly studied the rank order between different motives. In these studies, environmental motives were sometimes ranked high by adopters (cf. Caird et al., 2008; Fischer, 2008; Nygrén et al., 2015; Warren, 2010) and sometimes relatively low (cf. Balcombe et al., 2014; Vasseur and Kemp, 2015). 
Moreover, in most of the studies, instrumental motives were very high on the ranking as well - in several cases actually higher than environmental motives (cf. Balcombe et al., 2014; Mbzibain et al., 2013; Vasseur and Kemp, 2015). Non-economic instrumental motives (e.g. interest in technology or practical problems) were generally ranked lower than economic instrumental motives in the studies where they were included (cf. Balcombe et al., 2014; Fischer, 2008; Vasseur and Kemp, 2015) and symbolic motives were only mentioned in a few studies and then often ranked relatively low (cf. Balcombe et al., 2014; Nygrén et al., 2015). Although there are some common patterns, there are, thus, also exceptions and contradictory results.

Second, the available empirical evidence is somewhat biased in terms of the adopter types and types of RETs it covers. Table 1 gives an overview of the previous studies, including the RETs they cover, the country they study, the adopter segments they focus on and the sample type and size they are based on. This overview identifies two main biases:

- Bias towards household adoption. With the exception of one study of farmers (reported in two of the papers) and one of SMEs, all studies focus on the motives of consumers or households to adopt RET. However, although households are important adopters in many countries, there are also other types of adopters. For example, Bergek et al. (2013) identify seven additional adopter categories in Sweden and according to data supplied by trend:research (2013) about 40 percent of the German renewable electricity generation capacity is controlled by strategic and institutional investors. The focus on household adoption then becomes somewhat problematic, since there are some indications that different 
adopter categories have different motives to adopt (cf. Sidiras and Koukios, 2004).

- Bias towards microgeneration technologies (especially solar PV systems). Although micro-generation technologies show great potential in general, the diffusion patterns in many countries include a mix of small- and large-scale technologies (European Commission, 2015) and different types of technologies are also relevant in different local contexts and countries (Eurostat, 2015a). The focus on solar PV systems and other micro-generation technologies therefore limits the usefulness of the available studies for policy makers in countries and regions where such technologies are not the most relevant ones, especially considering that there is some evidence that the relative importance of different motives varies between technologies (cf. Caird et al., 2008).

In addition to these weaknesses, we can also note that the geographical coverage of the studies is limited to a small number of countries (with a slight bias towards the UK) and that the number of adopters included in the studies with only a few exceptions is quite small. Although we fully acknowledge the importance of deep case studies to identify and explore motives and understand complex adoption processes, it is difficult to know to what extent the relative frequency and importance of the motives identified in such small-scale studies are representative for a larger set of adopters - even for the same technologies, adopter categories and countries.

Taken together, these biases imply that there is a real risk that the findings summarized in the previous sections do not hold across adopter categories, technologies and countries. More studies are, therefore, needed to allow for generalization by replication 
(Yin, 1984) ${ }^{4}$ and to build up a thorough understanding of what motivates nontraditional adopters, such as individuals, diversifying companies and other organizations, to adopt RETs. This is important not the least for policy makers who want to stimulate diffusion of RETs, since the best way to achieve large-scale diffusion in a specific national or local context might not be through solar PV adoption by households (to stretch the argument a bit).

Against this background, the contribution of this paper is to complement the previous literature with a relatively large, survey-based study of RET adoption in Sweden, which covers different categories of non-traditional adopters as well as different RETs. Our first research question relates to the relative importance of different motives in the population as a whole:

RQ1: What are the main motives for non-traditional adopters to adopt RETs in Sweden and what is the relative importance of different motives?

Considering the two identified biases in the available empirical evidence, our second research question aims at identifying potential differences in motives between different adopter categories and RETs:

RQ2: How do motives and their relative importance differ between (a) different adopter categories and (b) different RETs?

\footnotetext{
${ }^{4}$ Replication logic implies that subsequent cases are treated as repeated experiments. Cases that confirm previously identified relationships strengthen the confidence in the validity of the relationships, while cases that disconfirm the identified relationships give the researchers a chance to improve the theory (Eisenhardt, 1989).
} 


\section{Methodology and data}

\section{I The case of Sweden}

In order to complement and expand the available empirical evidence regarding motives to adopt RETs, we chose the case of Sweden. This case is suitable for this purpose for three main reasons.

First, Sweden represents a successful example of RET diffusion. Sweden has one of the highest shares of renewable electricity generation in Europe $63.3 \%$ if the gross electricity consumption in 2014) (Eurostat, 2015a). Although much of this consists of large-scale hydro power, newer RETs such as wind power, biomass CHP and solar PV cells have increased as well in the last decades. Between 2003 and 2016, at least 22 TWh of new renewable electricity production was added (Swedish Energy Agency and Norwegian Water Resources and Energy Directorate (NVE), 2016). This corresponds to approximately 14 percent of the Swedish electricity supply.

Second, a prerequisite for studying adoption motives is that there is a sufficient number and variety of adopters. The Swedish electricity market was liberalized in 1996, which makes it possible for all types of actors to adopt RETs and sell (part of) the electricity they produce. A recent study showed that the Swedish RET adopter population is indeed quite heterogeneous and includes actors with different (industrial) backgrounds, organizational forms and scales of production (Bergek et. al, 2013).

Third, because Sweden has a tradable green certificate (TGC) system to support RE production, from which all RE adopters (with some restrictions) can receive certificates for 15 years for each new plant, there are reliable data on the Swedish RET adopter population. The fact that RET adopters are under the influence of an economic policy 
instrument also makes it possible to test many policy-makers' (implicit) assumption that RET adopters take the decision to adopt based on economic motives.

\subsection{Study design}

The empirical part of the paper is based on a study of non-traditional RET adopters in Sweden. These adopters include new categories of actors who recently joined the renewable electricity production, such as farmers, municipalities, diversifying companies (e.g. pulp and paper companies, landlords, retailing companies) or cooperatives. There are two main reasons for this focus. First, these non-traditional adopters own a majority of the RET plants and installed RET capacity in Sweden (Bergek et al., 2013). Understanding their motives is, thus, key to explaining the diffusion of RETs in Sweden until now. Second, the literature review in Section 2 identified a number of gaps and biases in previous studies of adoption motives, which we specifically want to address in this paper. Since these studies are focused on non-traditional adopters, a necessary first step is to make a study of similar types of adopters, but with a larger sample and more explicit consideration to different adopter categories and RETs within that sample. Future studies should include also the motives of more traditional types of adopters, such as utilities and large energy companies, in order to confirm or challenge the implicit assumption in the energy economics literature (and among policy makers) that they are primarily driven by economic motives. That is, however, beyond the scope of this paper.

The study was designed in two steps. First, we conducted interviews with some of the RET adopters in focus in our study. In these interviews, we particularly asked questions about the adopters' motives. Through this process, we were able to identify 12 arguments for adopting RETs, which we used as a basis for the second study design step. 
Second, we designed a survey, which included four main sections: a) questions about the characteristics of the adopter (e.g. size, main activity and position in the organization), b) questions about the RE plant (e.g. type of technology, plant size and annual production), c) questions about the adopter's first RET adoption (e.g. origin of the idea to adopt, adoption motives and implementation strategies and challenges) and d) questions about policy and market conditions (e.g. types of governmental support received, importance of the support for the adoption decision and for adoption satisfaction, impact of electricity prices for the adoption decision and for adoption satisfaction). In this paper, we focus on the questions about motives included in part $\mathrm{C}$.

The questions about motives were based on the arguments identified in the explorative interviews, as described above. In Table 2, illustrative quotes from the interviews are provided for each survey question to explain how they were derived and how they should be interpreted. The table also includes the "tags" used to refer to each motive in the empirical analysis.

In the survey, we asked respondents to consider how important each motive was for their decision to adopt the RET in question and indicated this on a 5-point Likert scale (from 1 - of decisive importance to 5 - of no importance at all). In order to match the questions to the specific contexts of different adopter categories and limit the risk of misunderstandings leading to measurement errors, the survey was designed in four slightly different versions: one for public organizations (including municipalities), one for individuals, one for companies and one for associations (including cooperatives). We also tested the questions on a small sample of adopters to make sure they could interpret them correctly before we sent out the survey. This resulted in some modifications of the questions. 
Table 2. Motives, statements used in the survey questionnaire, illustrative quotes and tags.

\begin{tabular}{|c|c|c|c|c|}
\hline Type of motive & & Statement in survey questionnaire & Illustrative quotes from explorative interviews & $\begin{array}{l}\text { Tag in figures } \\
\text { and tables }\end{array}$ \\
\hline \multirow[t]{13}{*}{ Instrumental } & \multirow[t]{9}{*}{ Economic } & \multirow[t]{2}{*}{$\begin{array}{l}\text { To produce renewable electricity allowed the } \\
\text { organisation to pay lower taxes (1). }\end{array}$} & $\begin{array}{l}\text { "At the time, I was working at an accounting company and that's } \\
\text { how I became aware about the possibility to write off some taxes } \\
\text { by investing in wind power". }\end{array}$ & Tax reduction \\
\hline & & & $\begin{array}{l}\text { "The goal of the investment was to be able to benefit from the } \\
\text { energy tax exemption on self-produced electricity". }\end{array}$ & \\
\hline & & \multirow[t]{2}{*}{$\begin{array}{l}\text { To produce renewable electricity was a way for } \\
\text { the organisation to reduce its energy costs }(2) \text {. }\end{array}$} & $\begin{array}{l}\text { "Investing in renewable electricity represented savings in energy } \\
\text { costs reaching } 34 \% \text { per square meter". }\end{array}$ & $\begin{array}{l}\text { Energy cost } \\
\text { reduction }\end{array}$ \\
\hline & & & $\begin{array}{l}\text { "For the members of our energy cooperative, investing is not } \\
\text { about making money. Instead, it is about being able to buy } \\
\text { electricity at cost price." }\end{array}$ & \\
\hline & & \multirow[t]{2}{*}{$\begin{array}{l}\text { Renewable electricity production was a good } \\
\text { way for the organisation to earn money. (4) }\end{array}$} & $\begin{array}{l}\text { "By maximizing the electricity production within the production } \\
\text { process, we can make a lot of money". }\end{array}$ & $\begin{array}{l}\text { Economic } \\
\text { revenues }\end{array}$ \\
\hline & & & $\begin{array}{l}\text { "At that time, after evaluating different investments, it turned } \\
\text { out that renewable electricity was the most profitable one. }\end{array}$ & \\
\hline & & \multirow[t]{2}{*}{$\begin{array}{l}\text { The organisation had access to a specific } \\
\text { resource needed for renewable electricity } \\
\text { production (e.g. land, roof, biomass, stream) (6) }\end{array}$} & $\begin{array}{l}\text { "Above all, I wanted to exploit the resource that was available on } \\
\text { my land. Other farmers kept letting me that it was a mistake to } \\
\text { have a stream of water running on my land without trying to do } \\
\text { something out of it". }\end{array}$ & $\begin{array}{l}\text { Access to an } \mathrm{RE} \\
\text { resource }\end{array}$ \\
\hline & & & $\begin{array}{l}\text { "For us, producing electricity is a way to exploit the steam and to } \\
\text { increase of the efficiency of our process." }\end{array}$ & \\
\hline & & $\begin{array}{l}\text { There was a need to broaden the business to new } \\
\text { activities (12). }\end{array}$ & $\begin{array}{l}\text { "We were going to retire and we felt that we needed to find } \\
\text { something new, exciting and not too time-consuming". }\end{array}$ & Diversification \\
\hline & \multirow{4}{*}{$\begin{array}{l}\text { Non- } \\
\text { economic }\end{array}$} & \multirow{2}{*}{$\begin{array}{l}\text { To produce renewable electricity was a good way } \\
\text { for the organisation to become independent (3). }\end{array}$} & "It is a great feeling to be self-sufficient in electricity". & Independence \\
\hline & & & $\begin{array}{l}\text { "To be able to produce my own energy with the farm's resources } \\
\text { was the driving idea". }\end{array}$ & \\
\hline & & \multirow{2}{*}{$\begin{array}{l}\text { There was an individual in the organisation who } \\
\text { was interested in the technology and who } \\
\text { pursued the issue. (5) }\end{array}$} & $\begin{array}{l}\text { "My son was working at Vestas and he was very interested in the } \\
\text { technology." }\end{array}$ & $\begin{array}{l}\text { Interest in the } \\
\text { technology }\end{array}$ \\
\hline & & & $\begin{array}{l}\text { "Being able to develop our own project gave us an incredible } \\
\text { self-esteem; it was like playing reality Lego". }\end{array}$ & \\
\hline
\end{tabular}


There was a renovation need, which made

renewable electricity production possible. (9)
"We needed to change the boiler anyway so we thought 'why not investing a bit more and get as much profit as possible out of it by combining it with electricity production?"'.

"When the association of tenants took the decision to renovate the roofs, we realized that installing solar panels at the same time would be a way to achieve two ends with one single effort".

A new regulation or law forced the organisation to find a solution, which resulted in new renewable electricity production. (10)

\section{Environmental}

To produce renewable electricity is good for the
environment. (7)

There was a surplus of material or other

resources that were not used in an efficient way. (11)
"When the changes in the landfill regulations took place, we had to find a solution to get rid of all the recycled paper sludge. We evaluated different options and chose renewable electricity production because it was the least expensive one".

"It was our commitment to the environment that led us to invest in renewable electricity. We did not want nuclear power; we wanted something else!"

"One of my goals in to contribute to a circular economy. Investing in renewable electricity is a step in that direction".

"In a context where the company developed the vision that its role was to contribute to making Earth's resources last longer, our driving force for investing in renewable electricity

production was to make use of the methane produced in the landfill".

"When the local energy company informed us that they were not anymore interested in buying the methane produced in our landfill, we had to look for new options. Renewable electricity looked that the most efficient one at the time".

\section{Regulation} (forcing)

\section{Environmental}

benefit

Surplus of resources

"The company invested in wind power because it really wants to profile itself as a company that strives to make a difference in society."

"As a wind developing company, investing and owing our own plants is important for our credibility".
Image 
The survey was sent out to 2,157 unique adopters, who were identified through an official government database of all Swedish plants (and their owners) that were registered for tradable green certificates in July 2012. As explained above, this corresponds to almost the entire population of non-traditional RET adopters in Sweden. ${ }^{5}$ All potential respondents had adopted at least one RET sometime between 1990 and 2011 (Bergek et al., 2013).

The link to the Internet survey was sent to the email addresses that were registered in the official TGC database. If no such address was available, we sent the link to the Internet survey by postcard. We also offered a possibility to receive and answer the survey in a paper version or over the phone (with the assistance of a researcher) in order to enable people who did not have Internet access or who did not feel comfortable with computers and surveys as such to participate. In order to increase the response rate, we sent out two reminders, either by email or by postcard.

We received 607 answers and after cleaning data from empty or discontinued questionnaires, 602 answers remained. ${ }^{6}$ This corresponds to a response rate of $28 \%$, which is within the average for Internet surveys (Deutskens et al., 2006; Kaplowitz et al., 2004). Sample characteristics indicate a good representativeness of the respondent group (see Table 3). Most notably, respondents represented all non-traditional RE adopter categories and all main RE technologies (i.e. hydropower, wind power, solar power and biomass-based power) identified by Bergek et al. (2013) in a previous study.

\footnotetext{
${ }^{5}$ It should be noted that it is not compulsory for electricity producers to participate in the TGC system. This implies that some RE adopters who choose not to apply for certificates are not included in the database. This especially concerns small-scale solar PV plants. Nevertheless, we would argue that the database is a good approximation of the total population of RET adopters at that point in time.

6 Of these, 26 used the paper survey or filled out the survey over the phone with the assistance of a researcher.
} 
There is, however, an overrepresentation of individuals in comparison with the entire population of non-traditional RET adopters, whereas companies (IPPs and diversified companies) are underrepresented. There is also an overrepresentation of solar power adopters (which corresponds well with the relatively large share of individuals). These over- and under- representations would have been problematic if certain adopter categories or RETs had been directly associated with one particular motive. However, as illustrated in Figures 2 and 3, the fact that a diversity of motives is present within each adopter category and RET eliminates the risks associated with over- or under representation of respondent types with regard to motives.

Table 3. Sample characteristics

\begin{tabular}{|c|c|c|c|c|}
\hline & & $\begin{array}{l}\text { Number of } \\
\text { respondents }\end{array}$ & $\begin{array}{l}\text { Share of } \\
\text { respondents }\end{array}$ & $\begin{array}{c}\text { Share in entire } \\
\text { population of RET } \\
\text { adopters }\end{array}$ \\
\hline \multirow[t]{6}{*}{ Investor categories } & Individuals & 321 & $53 \%$ & $13 \%$ \\
\hline & Associations & 29 & $5 \%$ & $7 \%$ \\
\hline & Municipalities & 9 & $2 \%$ & $4 \%$ \\
\hline & Diversified companies & 109 & $18 \%$ & $29 \%$ \\
\hline & IPPs & 134 & $22 \%$ & $47 \%$ \\
\hline & Total & 602 & $100 \%$ & \\
\hline \multirow[t]{7}{*}{ RET } & Wind power & 188 & $31 \%$ & $49 \%$ \\
\hline & Solar power & 197 & $33 \%$ & $16 \%$ \\
\hline & Biomass & 8 & $1 \%$ & $4 \%$ \\
\hline & Hydropower & 192 & $32 \%$ & $30 \%$ \\
\hline & Other & 8 & $1 \%$ & $0 \%$ \\
\hline & Not available & 11 & $2 \%$ & $0 \%$ \\
\hline & Total & 604 & $100 \%$ & $100 \%$ \\
\hline
\end{tabular}

Data were first analysed in a descriptive way, i.e. we analysed the relative importance of all motives in terms of both mean values and the distribution of answers along the Likert 
scale for all respondents and for different adopter categories and RETs. ${ }^{7}$ We then did some statistical tests to determine if there were any statistically significant differences between different adopter categories and RETs with regard to the importance of different motives. This was done through one-way analysis of variance (ANOVA) for each motive, followed by Post Hoc tests for those motives where a significant difference between sub-categories was found.

\subsection{A brief note on support to RET diffusion in Sweden}

As mentioned above, the survey respondents were derived from the Swedish TGC system database. This implies that all the adopters in our study have received certificates for their RE production.

There have also been other support systems in place for RETs in Sweden - both prior to and in parallel with the TGC system. For wind power, there have been investment subsidies (1991-2003), an environmental bonus (tax reduction) (1991-2009) and support for large-scale offshore and inland sea wind pilot projects (2003-2012). Investment subsidies have also existed for biomass-based combined heat and power plants (1991-2003) and small-scale solar PV systems (2009 - ). In addition, the fee for feeding electricity into the grid is reduced for plants under 1,500 kW and, at the time of the survey, all adopters who were not professionally electricity retailers were partly exempted from electricity tax. ${ }^{8}$

\footnotetext{
7 It should be noted that this analysis does not take into account the installed capacity associated with each adopter, which implies that we cannot draw any conclusions regarding the importance of specific motives for the overall diffusion process, but only for individual adoption decisions.

8 They only had to pay tax for the amount of electricity they produced that surpassed their own consumption. Since 2015, the rules have changed. Micro-scale producers can now claim a tax reduction on the electricity they produce and consume, up to 30,000 kWh/year. Larger-scale production is no longer eligible for any tax reduction.
} 
According to our survey, roughly $50 \%$ of the adopters have received other kinds of policy support than TGCs (for the most part some kind of investment subsidy). However, it should be noted that many of the RE adopters included in this study come from other (industrial) backgrounds than energy, which implies that some of them also may have been exposed to policy instruments directed at their main industry, for example industry-specific regulations, taxes or support systems. In many cases, such policies have a larger influence on RET adoption than policies to support RET diffusion (Mignon and Bergek, 2016), but it is beyond the scope of this paper to explore the details of this influence further.

\section{Empirical findings and discussion}

\section{I Motives to adopt RETs in Sweden: overall findings}

Figure 1 shows the importance assigned to each motive by the survey respondents. A first observation is that all the categories of motives identified in Section 2 are of some importance also in the Swedish context: economic, instrumental motives (e.g. access to an RE resource, economic revenues or an energy cost reduction), non-economic instrumental motives (e.g. interest in the technology, independence and forcing regulations), environmental motives (environmental benefits and or a resource surplus) and symbolic motives (e.g. image).

It should be noted that each of these motives was described as being "of decisive importance" to some of the respondents and "of no importance at all" to other adopters, which shows the heterogeneity of adoption motives. 


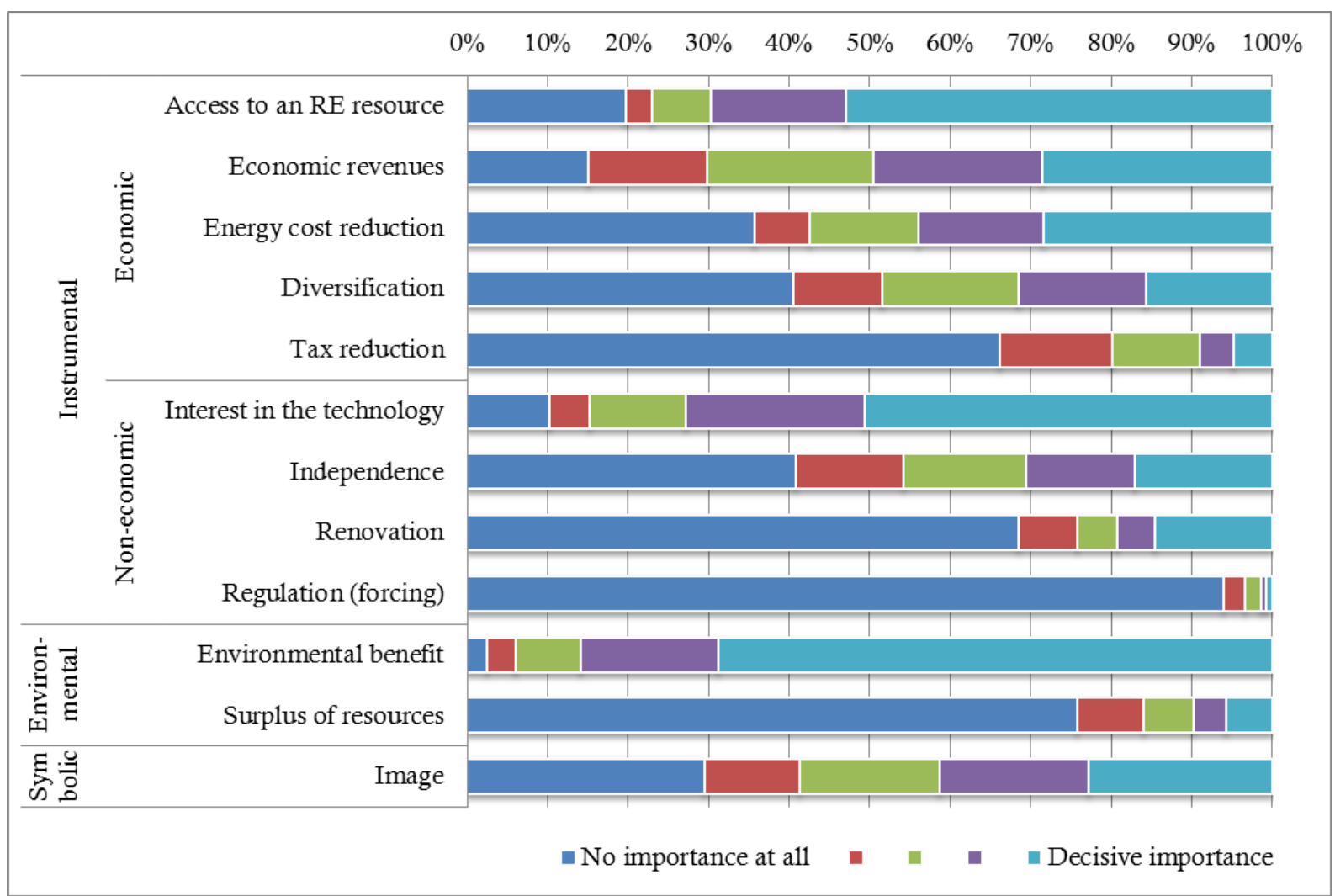

Figure 1: Importance assigned to different motives by all respondents (falling share of "decisive importance" within each motive category).

With regard to the relative importance of motives, three motives qualified as being "of decisive importance" to more than 50 percent of the respondents and these were also the motives with the lowest mean values (i.e. the greatest importance) (see Table 4): that renewable electricity production is good for the environment $(\mu=1.54)$, that someone in the organisation was interested in the technology $(\mu=2.02)$ and that the adopter had access to an RE resource (e.g. a piece of land, a roof, some biofuels or a watercourse) ( $\mu=2.20$ ). Between 20 and 30 percent of the respondents stated that it was of decisive importance for their adoption decision that renewable electricity production was a good way achieve economic revenues $(\mu=2.67)$ or energy cost reductions $(\mu=3.06)$ or was good for the adopter's image $(\mu=3.07)$. Between 10 and 20 percent stated that it was of decisive importance that there was a need to diversify to new business activities $(\mu=3.45)$, that renewable electricity production was a good way to become independent $(\mu=3.48)$ or that a renovation project made electricity 
production possible $(\mu=4.10)$. Only a very small share of the respondents stated that the opportunity to achieve tax reductions $(\mu=4.33)$, a surplus of resources $(\mu=4.44)$ or a forcing regulation $(\mu=4.88)$ was of decisive importance for their adoption decision.

It can be noted that although an environmental motive was attached the greatest importance on average, both the first and second runner up were instrumental motives - one non-economic (interest in technology) and one economic (access to an RE resource). This is largely in line with the findings in previous studies (see Section 2). The high importance attached to having an interest in the technology as such is also different from most previous literature (see Section 2), but supports the findings of some studies (e.g. Nygrén et al., 2015; Palm and Tengvard, 2011).

Moreover, in contrast to previous literature (e.g. Balcombe et al., 2014; Caird et al., 2008; Mbzibain et al., 2013), energy cost reductions were not the most important economic instrumental motive for Swedish RET adopters. This might reflect the relatively low electricity prices in Sweden in the studied period. Instead, having access to an RE resource and the potential economic revenues seem to have been of greater importance. The importance of having access to an RE resource is of particular interest from a policy perspective, since it indicates that many adopters design their adoption project around an available resource rather than looking for the best location or input material for their RET plant. The importance of economic revenues is consistent with especially the energy economics literature (see Section 2) and shows that at least some adopters seem to base their adoption decisions on traditional, economic investment criteria.

Apart from an interest in the technology, non-economic instrumental motives were not described as very important motives for RET adoption in Sweden. This is largely in line 
with previous literature (cf. Section 2). This is also the case for symbolic motives, although image was ranked higher than in most previous studies (cf. Section 2).

It should be noted that most of the respondents attached at least some importance to several motives, which supports statements made in previous literature (cf. Stern, 2000). In fact, adopters tend to mix different types of motives. For instance, environmental, instrumental and symbolic instrumental motives can interplay in an adoption decision.

Table 4: Mean values for different motives.

\begin{tabular}{lccl}
\hline & Mean & SD & Motive category \\
\hline Environmental benefit & 1.54 & 0.96 & Environmental \\
Interest in the technology & 2.02 & 1.32 & Instrumental, non-economic \\
Access to an RE resource & 2.20 & 1.57 & Instrumental, economic \\
Economic revenues & 2.67 & 1.41 & Instrumental, economic \\
Energy cost reduction & 3.06 & 1.67 & Instrumental, economic \\
Image & 3.07 & 1.55 & Symbolic \\
Diversification & 3.45 & 1.52 & Instrumental, economic \\
Independence & 3.48 & 1.54 & Instrumental, non-economic \\
Renovation & 4.10 & 1.49 & Instrumental, non-economic \\
Tax reduction & 4.33 & 1.12 & Instrumental, economic \\
Surplus of resources & 4.44 & 1.14 & Environmental \\
Regulation (forcing) & 4.88 & 0.52 & Instrumental, non-economic \\
\hline
\end{tabular}

N.B. The lower the mean value, the higher importance. $(1=$ "of decisive importance" and $5=$ "of no importance at all").

\subsection{Differences between adopter categories and RETs with regard to motives}

In order to provide an answer to RQ2, we investigated whether there were any differences in terms of motives between different adopter categories and between adopters of different RETs.

\subsubsection{Differences between adopter categories}

Figure 2 illustrates the mean values for all twelve motives for individuals, associations, diversified companies, municipalities and IPPs. This shows that in general the 
differences between adopter categories with regard to the importance they attached to different motives are quite small. There is no clear pattern in terms of an association of some types of motives (instrumental, environmental and symbolic) with particular adopter categories. However, IPPs and municipalities seem to distinguish themselves with regard to some of the motives (e.g. economic revenues, energy cost reduction and image).

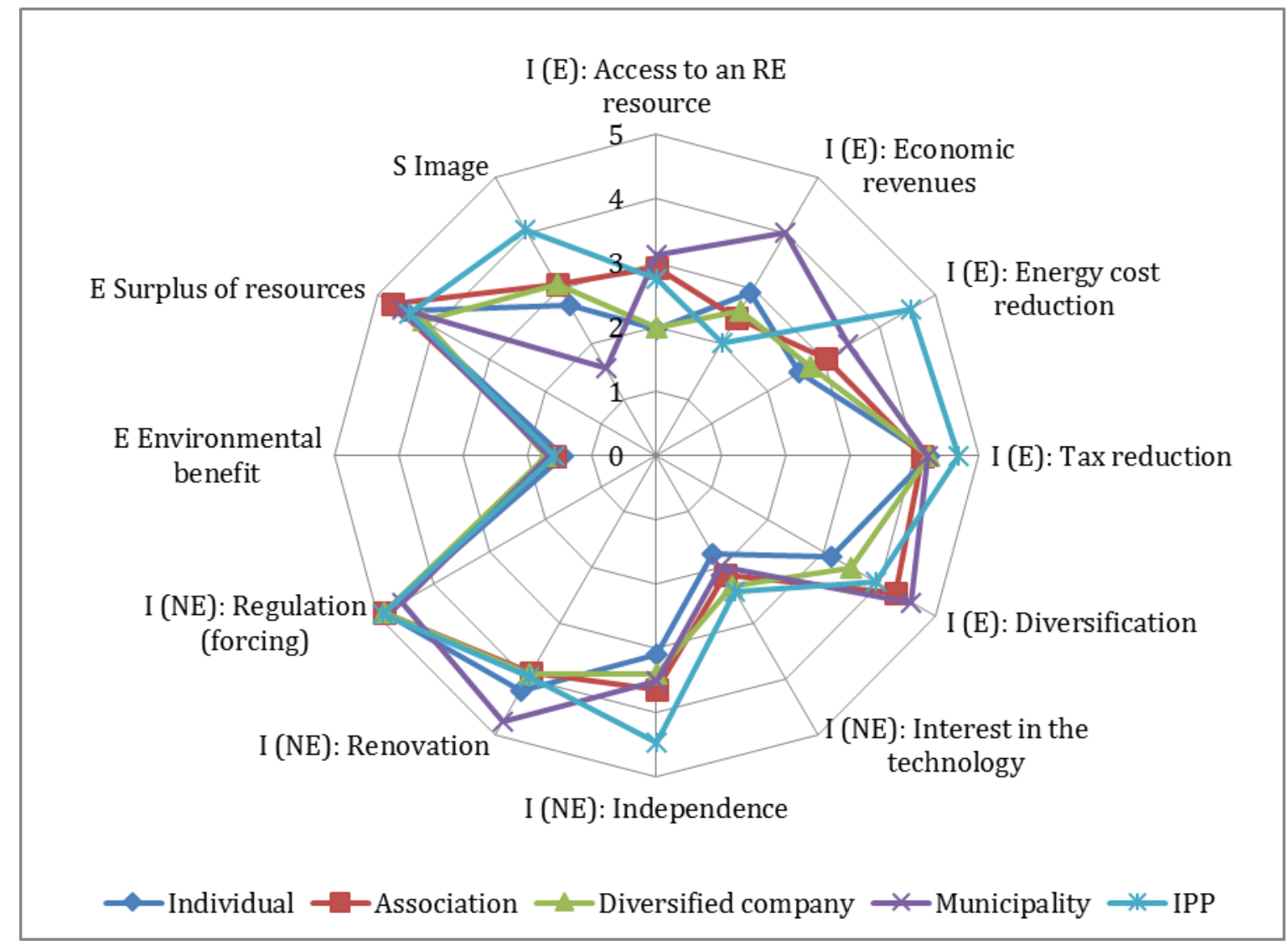

Figure 2: Importance of different motives for different adopter categories sorted according to motive category (mean value, all respondents; mean values increase clockwise within each category.). N.B. 1 = "of decisive importance" and 5 = "of no importance at all".

As described in Section 3, we performed ANOVA tests in order to determine whether the differences in means between the adopter categories were statistically significant. Table 5 presents the result of twelve separate one-way ANOVA tests with associated Post Hoc tests for those motives where a significant difference between adopter categories types was found. 
These tests show that there is no significant difference between adopter categories with regard to the importance they attached to environmental benefits, forcing regulations, renovations or surplus of resources. They also show that, as indicated by Figure 2, IPPs differ from other adopter categories with regard to several of the motives. Most notably, they attached lower importance than individuals (and in some cases other adopter categories - especially diversified companies) to tax reductions, energy cost reductions, independence, interest in the technology, access to an RE resource, image and diversification. They also emphasised economic revenues more than individuals, municipalities and diversified companies.

The tests also confirm that municipalities attached lower importance to economic revenues than all other investor categories apart from individuals. Municipalities also attached greater importance to image as a motive than diversified companies and IPPs.

Individuals attached greater importance than IPPs and diversified companies to interest in technology motive. They also seem to have found diversification more important than associations, municipalities and IPPs. Here it should be considered that the category 'individuals' includes some farmers and other business owners, whose businesses are not registered as a company or association but have other organisational forms. From the interviews we know that especially many farmers adopt RETs as a "third leg" to offset the risks involved in their crop (or livestock) and forest businesses. Finally, having access to an RE resource was a more important motive for individuals than for IPPs and associations. Judging by the interviews, this probably reflects a tendency for associations and IPPs to search for an appropriate location for their solar and wind power plants rather than designing their project around an existing roof or piece of land. 
Diversified companies differed from IPPs with regard to several motives, which is not surprising considering that they per definition have a broader business scope and, thus, most probably are subject to different economic conditions and also have other previous knowledge and experiences to base their decisions on. For the same reasons, it is rather surprising that they did not differ more from individuals and associations.

To sum up, there are differences between different adoption categories with regard to their adoption motives, which was also hinted at in some previous studies (cf. Sidiras and Koukios, 2004). However, the picture that emerges is complex and the identified differences are not always easy to explain. No motive is clearly associated with only one adopter category and two investor categories can differ with respect to one motive but be very similar with respect to other motives. The only clear pattern is that IPPs and individuals seem to be each other's opposites when it comes to motives to invest in RETs. One explanation for this might be that it is more likely that an individual adopter would register a separate company (and accept the costs associated with that) if electricity production was seen as a separate business intended to generate economic revenues than if the motive was to achieve energy cost reductions or improve one's image. 
Table 5. Mean values for each motive for five adopter categories. The differences between the groups' means have been analyzed with one-way ANOVA (F-values are provided in the 5th column). The last column shows significant mean differences according to Post Hoc testing.

\begin{tabular}{|c|c|c|c|c|c|c|c|}
\hline \multirow[t]{2}{*}{ Motive } & \multicolumn{5}{|c|}{ Adopter categories } & \multirow[t]{2}{*}{ F-value } & \multirow{2}{*}{$\begin{array}{l}\text { Significant mean } \\
\text { differences }^{\mathrm{a}}\end{array}$} \\
\hline & $\begin{array}{l}\text { Associ- } \\
\text { ation }\end{array}$ & $\begin{array}{l}\text { Munici- } \\
\text { pality }\end{array}$ & $\begin{array}{l}\text { Indivi- } \\
\text { dual }\end{array}$ & IPP & $\begin{array}{l}\text { Divers- } \\
\text { ified }\end{array}$ & & \\
\hline Tax reduction & 4.12 & 4.22 & 4.23 & 4.69 & 4.23 & $4.152 * *$ & $\begin{array}{l}\text { individual }<\mathrm{IPP} * * \\
\text { diversified }<\mathrm{IPP} *\end{array}$ \\
\hline $\begin{array}{l}\text { Energy cost } \\
\text { reduction }\end{array}$ & 3.04 & 3.44 & 2.57 & 4.56 & 2.75 & $39.802 * * *$ & $\begin{array}{c}\text { association }<\mathrm{IPP} * * * \\
\text { individual }<\mathrm{IPP} * * * \\
\text { diversified }<\mathrm{IPP} * * *\end{array}$ \\
\hline Independence & 3.63 & 3.50 & 3.10 & 4.46 & 3.39 & $18.128 * * *$ & $\begin{array}{l}\text { individual < IPP*** } \\
\text { diversified < IPP**** }\end{array}$ \\
\hline $\begin{array}{l}\text { Economic } \\
\text { revenues }\end{array}$ & 2.48 & 4.00 & 2.93 & 2.03 & 2.59 & $11.526 * * *$ & $\begin{array}{c}\text { association }<\text { municipality } * \\
\text { IPP }<\text { municipality } * * * \\
\text { IPP }<\text { individual } * * * \\
\text { IPP }<\text { diversified } * \\
\text { diversified }<\text { municipality* }\end{array}$ \\
\hline $\begin{array}{l}\text { Interest in the } \\
\text { technology }\end{array}$ & 2.15 & 2.00 & 1.76 & 2.43 & 2.33 & $7.486 * * *$ & $\begin{array}{c}\text { individual < IPP*** } \\
\text { individual }<\text { diversified } * *\end{array}$ \\
\hline $\begin{array}{l}\text { Access to an } \mathrm{RE} \\
\text { resource }\end{array}$ & 2.93 & 3.11 & 1.96 & 2.74 & 1.99 & $8.348 * * *$ & $\begin{array}{c}\text { individual }<\text { association* } \\
\text { individual }<\text { IPP } * * * \\
\text { diversified }<\text { association* } \\
\text { diversified }<\text { IPP** }\end{array}$ \\
\hline $\begin{array}{l}\text { Environmental } \\
\text { benefit }\end{array}$ & 1.59 & 1.67 & 1.46 & 1.58 & 1.71 & 1.319 & - \\
\hline Image & 3.08 & 1.56 & 2.71 & 4.06 & 3.08 & $20.568 * * *$ & $\begin{array}{c}\text { association }<\text { IPP* } \\
\text { municipality }<\text { IPP*** } \\
\text { municipality }<\text { diversified } * \\
\text { individual }<\text { IPP } * * *\end{array}$ \\
\hline Renovation & 3.89 & 4.78 & 4.22 & 3.96 & 3.93 & 1.670 & - \\
\hline $\begin{array}{l}\text { Regulation } \\
\text { (forcing) }\end{array}$ & 4.88 & 4.56 & 4.88 & 4.92 & 4.89 & 1.057 & - \\
\hline $\begin{array}{l}\text { Surplus of } \\
\text { resources }\end{array}$ & 4.73 & 4.56 & 4.50 & 4.43 & 4.18 & 1.745 & - \\
\hline Diversification & 4.28 & 4.56 & 3.14 & 3.94 & 3.49 & $9.828 * * *$ & $\begin{array}{c}\text { individual }<\text { association** } \\
\text { individual }<\text { municipality } * \\
\text { individual }<\text { IPP*** }\end{array}$ \\
\hline
\end{tabular}

$* \mathrm{p}<0.5, * * \mathrm{p}<0.01, * * * \mathrm{p}<0.001$.

\subsubsection{Differences between RETs}

Figure 3 illustrates the mean values for all twelve motives for small-scale hydro power, wind power and solar power. ${ }^{9}$ This gives a first indication that there are differences with regard to the importance adopters of different RETs attach to specific adoption motives, as suggested in some of the previous literature (cf. Caird et al., 2008). However, it does

\footnotetext{
${ }^{9}$ There were too few answers in the other technology categories to include them in the analysis.
} 
not seem like some types of motives (instrumental, environmental and symbolic) are associated with particular RETs in any clear way.

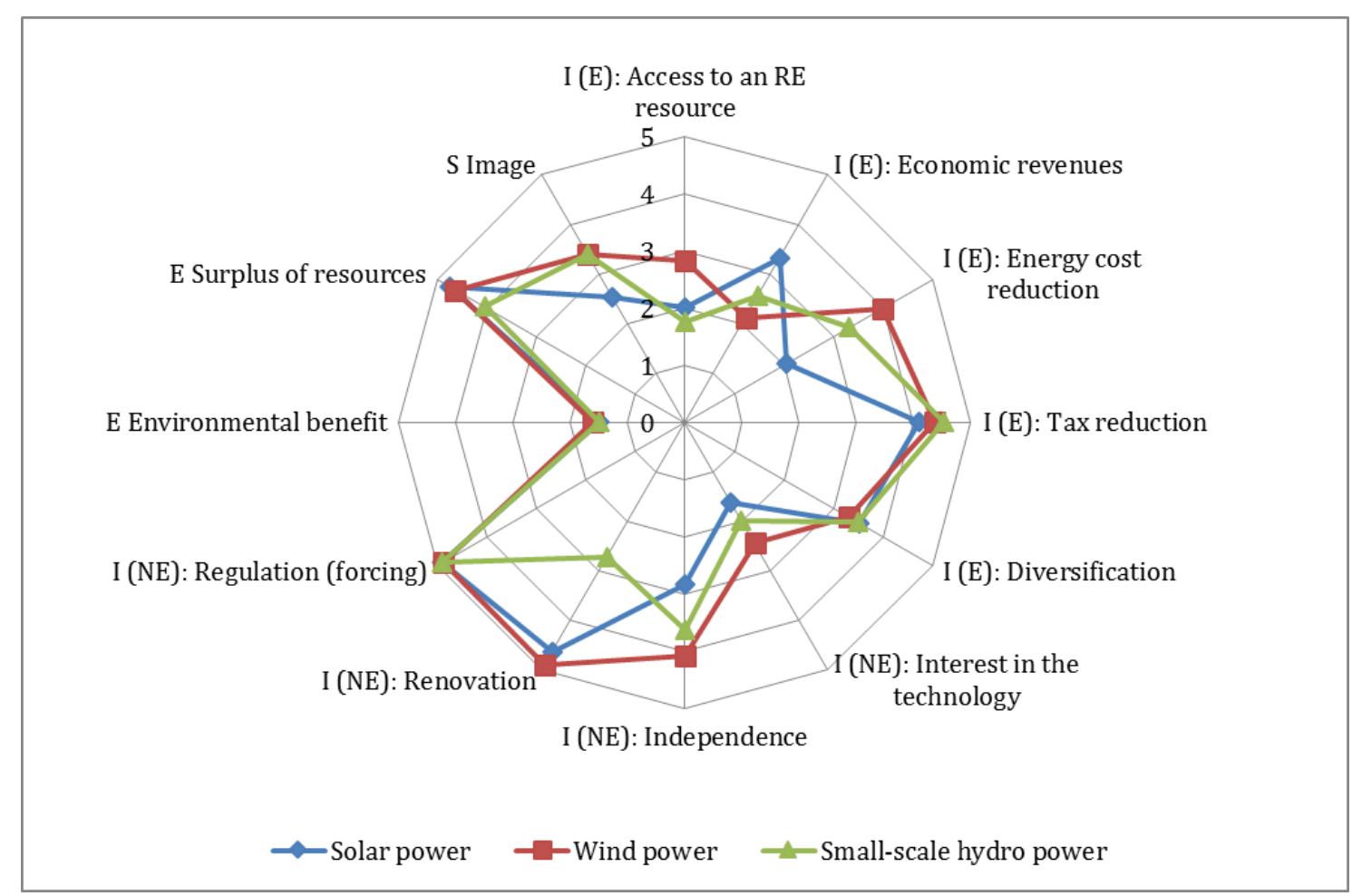

Figure 3: Importance of different motives for different RETs sorted according to motive category (mean value, all respondents; mean values increase clockwise within each category.). N.B. 1 = "of decisive importance" and 5 = "of no importance at all".

As described in Section 3, we performed ANOVA tests in order to determine whether the differences in means between the RETs were statistically significant. Table 6 presents the result of twelve separate one-way ANOVA tests with associated Post Hoc tests for those motives where a significant difference between energy sources was found.

These tests show that there is no significant difference between adopters of different RETs with regard to the importance they attached to environmental benefits, forcing regulations and diversification.

They also show that solar power adopters attached greater importance than small-scale hydro power adopters to energy cost reductions, independence and interest in technology and that small-scale hydro power adopters in turn attached greater 
importance to these motives than wind power adopters. The differences are, however, smaller for the interest in technology motive, than for the other two motives; adopters of all three RETs attached quite high importance to this motive and almost 40 percent of the wind power adopters in fact described it as being of decisive importance for their decision to invest. Wind power adopters also attached lower importance than solar and hydro power adopters to having access to an RE resource.

Finally, the tests show that hydro power adopters attached higher importance than wind and solar power adopters to renovation and surplus of resources and that wind power adopters attached more importance than hydro and solar power adopters to economic revenues (to which hydro power adopters attached higher importance than solar power adopters).

To sum up, there are some differences between different RETs with regard to adoption motives, but there is no clear pattern. Solar, small-scale hydro and wind power adopters share some motives, but differ from each other when it comes to other motives. Most notably, solar and wind power adopters differ in their assessment of some motives (with hydro power somewhere in between); wind power adoption seems to be motivated to a larger extent by economic revenues and to a lower extent by energy cost reductions, independence or interest in technology than solar power adoption (see Figure 3 and Table 6). This indicates that studies of the adoption of solar PV systems (and other micro-generation technologies) (e.g. Balcombe et al., 2014; Palm and Tengvard, 2011; Schelly, 2014; Vasseur and Kemp, 2015), might not be that relevant in a context where medium- to large-scale wind power is the most relevant RET. It also indicates that economic policies aimed at improving the profitability of RETs might be more relevant 
in such contexts than in a context dominated by solar PV adoption - unless policy

makers want to change the composition of the RET portfolio towards more wind power.

It should, however, also be noted that there is variation in terms of the importance adopters of the same RET attached to each motive. For example, even if the prospect of achieving tax reductions does not seem to have been an important motive for wind power adoption in general, about $3 \%$ of the wind power adopters still stated that it was of decisive importance to them.

Table 6. Mean values for each motive for three RETs. The differences between the groups' means have been analyzed with one-way ANOVA (F-values are provided in the $5^{\text {th }}$ column). The last column shows significant mean differences according to Post Hoc testing.

\begin{tabular}{|c|c|c|c|c|c|}
\hline \multirow[t]{2}{*}{ Motive } & \multicolumn{3}{|c|}{ RETs } & \multirow[t]{2}{*}{ F-value } & \multirow{2}{*}{$\begin{array}{c}\text { Significant mean } \\
\text { differences }\end{array}$} \\
\hline & $\begin{array}{l}\text { Hydro } \\
\text { power }\end{array}$ & $\begin{array}{l}\text { Solar } \\
\text { power }\end{array}$ & $\begin{array}{l}\text { Wind } \\
\text { power }\end{array}$ & & \\
\hline Tax reduction & 4.53 & 4.10 & 4.37 & $6.472 * *$ & solar < hydro** \\
\hline Energy cost reduction & 3.32 & 2.05 & 3.98 & $82.428 * * *$ & $\begin{array}{l}\text { hydro < wind } * * * \\
\text { solar }<\text { hydro } * * * \\
\text { solar }<\text { wind } * * *\end{array}$ \\
\hline Independence & 3.63 & 2.83 & 4.08 & $33.374 * * *$ & $\begin{array}{c}\text { hydro < wind* } \\
\text { solar }<\text { hydro*** } \\
\text { solar }<\text { wind } * * *\end{array}$ \\
\hline Economic revenues & 2.57 & 3.31 & 2.12 & $37.553 * * *$ & $\begin{array}{c}\text { hydro }<\text { solar**** } \\
\text { wind }<\text { hydro** } \\
\text { wind }<\text { solar } * * *\end{array}$ \\
\hline Interest in the technology & 1.98 & 1.61 & 2.44 & $20.235 * * *$ & $\begin{array}{c}\text { hydro < wind } * * \\
\text { solar }<\text { hydro* } \\
\text { solar }<\text { wind } * * *\end{array}$ \\
\hline Access to an RE resource & 1.75 & 2.02 & 2.82 & $23.867 * * *$ & $\begin{array}{l}\text { hydro < wind } * * * \\
\text { solar }<\text { wind } * * *\end{array}$ \\
\hline Environmental benefit & 1.50 & 1.50 & 1.61 & 0.863 & - \\
\hline Image & 3.39 & 2.54 & 3.39 & $19.201 * * *$ & $\begin{array}{l}\text { solar < hydro**** } \\
\text { solar < wind } * * *\end{array}$ \\
\hline Renovation & 2.73 & 4.62 & 4.9 & $176.001 * * *$ & $\begin{array}{l}\text { hydro }<\text { solar*** } \\
\text { hydro }<\text { wind } * * *\end{array}$ \\
\hline Regulation (forcing) & 4.90 & 4.90 & 4.89 & 0.014 & - \\
\hline Surplus of resources & 4.05 & 4.74 & 4.63 & $20.465 * * *$ & $\begin{array}{l}\text { hydro < solar*** } \\
\text { hydro < wind } * * *\end{array}$ \\
\hline Diversification & 3.50 & 3.53 & 3.30 & 1.155 & - \\
\hline
\end{tabular}

${ }^{*} \mathrm{p}<0.5,{ }^{* *} \mathrm{p}<0.01,{ }^{* * *} \mathrm{p}<0.001$. 


\section{Conclusions and policy implications}

\section{I Conclusions}

The purpose of this paper was to complement and expand the available empirical evidence regarding motives to adopt RETs by (1) identifying motives for RET adoption in Sweden and (2) investigating the relative importance of different RET adoption motives, both for the entire population of non-traditional RET adopters and for different adopter categories and RETs.

Our first research question concerned the main motives for non-traditional adopters to adopt RETs in Sweden and the relative importance of different motives. At a general level, our research confirmed findings from previous studies that RET adopters are a heterogeneous group with regard to motives (cf. Bauwens, 2016; Bergek et al., 2013): There are many different motives to adopt RETs and each adopter can have several different motives to adopt. It also confirmed the general importance of both environmental and economic motives for RET adoption.

However, our survey results also contradicted some of the findings in previous studies. First, having an interest in the technology was rated much higher than in previous studies. Second, although economic revenues and cost reductions were important motives, the most important economic motive was actually access to an RE resource, such as a roof or a piece of land suitable for wind power production.

Our second research question concerned differences between different adopter categories and RETs with regard to motives. Here, our findings provided important new insights. Indeed, while it could easily be assumed that specific adopter categories (e.g. households) or RETs (e.g. solar PV) are associated with particular motives, our study 
shows that there is variation within each adopter category and RET with regard to the importance adopters attach to particular motives. This points at the importance of overcoming the previous bias towards households and microgeneration technologies (especially solar PV) and broadening the empirical basis for policy recommendations.

Nevertheless, our broad respondent group allowed us to identify some previously unacknowledged differences with regard to both RETs and adopter categories. The most notable findings were (1) that wind and small-scale hydro power adopters differ significantly from solar power adopters by emphasising economic revenues (wind) or renovations (hydro) versus energy cost reductions (solar) as important motives, and (2) that IPPs differ from individuals and diversified companies (and in several cases also from other adopter categories) by attaching greater importance to economic revenues and less to most other motives. There were also some interesting differences between municipalities and other categories, especially with regard to their greater emphasis on image.

\subsection{Policy implications}

Large investments are needed to induce a large-scale diffusion of RETs (Jacobsson and Bergek, 2011). Yet, governments cannot undertake such investments alone (Wüstenhagen and Menichetti, 2012), and previous studies have shown that utilities and energy companies are not the primary drivers of this process (Bergek et al., 2013). In this context, new types of actors, such as the non-traditional RET adopters in focus in this study, are crucial since they represent a new potential source of capital. It is therefore important that policy makers consider the motives of such new RET adopters when designing policies to induce investments. 
As described in the previous section, our study shows that some motives are of higher importance to RET adopters in Sweden than in, for example, the UK and also that there are differences between adopter categories and RETs with regard to the importance they attach to different motives. An overall policy implication is, thus, that the policy suggestions made in previous literature, which are based on studies of specific adopter categories and technologies, do not necessarily apply to other contexts. Policy makers therefore need to carefully consider the context for which they are designing their policies.

At a more detailed level, the identified heterogeneity with regard to motives suggests that a combination of policy instruments might be needed to induce further adoption of RETs. For example, adopters who are motivated by the prospect of reducing their energy costs or becoming independent from utilities are likely to be more appealed by regulations guaranteeing the right to balance electricity production and consumption over longer time periods ("net metering") than by economic instruments that at best become an appreciated bonus for them. In contrast, the later might be more appealing to adopters who are motivated primarily by increasing their economic revenues.

It should also be noted that some motives might lead to adoption behaviours that are not ideal from the point of view of the energy system as a whole. For example, as noted in Section 4, adopters who choose to adopt an RET (in part) to exploit an RE resource they have access to (e.g. a piece of land) are unlikely to consider alternative resources (e.g. other locations for their plants). In some cases, they will thus deliberately refrain from maximising the full potential of their RETs (e.g. choose a location with sub-optimal wind conditions), and this might, in turn, imply that private capital and financial support from electricity consumers and government sources are not used as efficiently as possible. 
Policies might very well be needed to correct this, for example in terms of a required minimum level of plant efficiency to be eligible for economic support.

Our study also shows that motives in some respects differ between adopter categories. To the extent that policy makers want to see a flora of different types of RET adopters (and electricity producers) in the market, they therefore might need to consider implementing policies that appeal to different adopter categories. Most notably, the focus on household adoption in the previous literature might create a biased picture on what needs to be done to stimulate adoption, which excludes, for example, IPPs, municipalities and diversified companies.

Finally, our study shows that motives to some extent differ between RETs. This implies that policy makers need to consider which types of RETs they want to promote and possibly adjust their policy mix accordingly. In particular, they need to be aware that a specific policy instrument might create an unintended bias towards particular RETs if it reinforces motives associated more with them than with other technologies. For example, in the Swedish case, the TGC system improves the possibilities to generate economic revenues from renewable electricity production - a motive which in this study is primarily associated with wind power.

\subsection{Suggestions for further research}

The study reported in this paper complements previous studies by a studying a larger and more heterogeneous set of RET adopters. However, further studies are needed to allow for further empirical replication. Studies from other countries and adoption contexts would be especially welcome. It would also be interesting to see studies that challenge the implicit assumption in much of the previous literature that traditional RET 
adopters, such as utilities and large energy companies, are driven primarily by economic motives.

In addition, the fact that adopters of different RET differ from each other with regard to motives and that different types of adopters have different approaches to the economic motives indicates that there may be a connection between adoption motives and implementation strategy. For example, it seems reasonable to assume that adopters driven by the prospect of making money design their projects to maximise profits by carefully calculating the estimated return on investment, taking into account both the potential income from electricity production and green certificates and the associated risks. In contrast, adopters who are motivated by an interest in the technology may design their implementation process to maximise their own involvement with the technology. Such differences might have implications for plant efficiency and long-term commitment and it is therefore of interest to investigate the relationship between adoption motives and implementation strategies further.

\section{Acknowledgements}

The authors would like to thank Dr. Karl Wahlin for his advice concerning the design and analysis of the survey, but at the same time take full responsibility for any methodological mistakes made. Constructive comments from two anonymous reviewers are also gratefully acknowledged.

Funding: This work was supported by the Swedish Energy Agency [grant number 33685-1]. 


\section{References}

Arkesteijn, K., Oerlemans, L., 2005. The early adoption of green power by Dutch households: An empirical exploration of factors influencing the early adoption of green electricity for domestic purposes. Energy Policy 33, 183-196.

Awerbuch, S., 2000. Investing in photovoltaics: risk, accounting and the value of new technology. Energy Policy 28, 1023-1035.

Awerbuch, S., 2003. Determining the real cost: why renewable power is more costcompetitive than previously believed. Renewable Energy World 6, 53-61.

Balcombe, P., Rigby, D., Azapagic, A., 2013. Motivations and barriers associated with adopting microgeneration energy technologies in the UK. Renewable and Sustainable Energy Reviews 22, 655-666.

Balcombe, P., Rigby, D., Azapagic, A., 2014. Investigating the importance of motivations and barriers related to microgeneration uptake in the UK. Applied Energy 130, 403418.

Barradale, M.J., 2010. Impact of public policy uncertainty on renewable energy investment: Wind power and the production tax credit. Energy Policy 38, 76987709.

Bauwens, T., 2016. Explaining the diversity of motivations behind community renewable energy. Energy Policy 93, 278-290.

Bergek, A., Mignon, I., Sundberg, G., 2013. Who invests in renewable electricity production? Empirical evidence and suggestions for further research. Energy Policy $56,568-581$.

Bhattacharya, A., Kojima, S., 2012. Power sector investment risk and renewable energy: A Japanese case study using portfolio risk optimization method. Energy Policy 40, 6980.

Caird, S., Roy, R., Herring, H., 2008. Improving the energy performance of UK households: Results from surveys of consumer adoption and use of low- and zero-carbon technologies. Energy Efficiency 1, 149-166.

Deutskens, E., de Jong, A., de Ruyter, K., Wetzels, M., 2006. Comparing the generalizability of online and mail surveys in cross-national service quality research. Marketing Letters 17, 119-136.

Dinica, V., 2006. Support systems for the diffusion of renewable energy technologies-an investor perspective. Energy Policy 34, 461-480.

Eisenhardt, K.M., 1989. Building Theories from Case Study Research. Academy of Management Review 14, 532-550.

European Commission, 2015. Renewable energy progress report, Report from the Commission to the European Parliament, the Council, the European Economic and Social Committee and the Committee of the Regions, Brussels, 15.6.2015 $\operatorname{COM}(2015) 293$ final (including member state progress reports).

Eurostat, 2015a. Renewable energy statistics, URL: http://ec.europa.eu/eurostat/statisticsexplained/index.php/Renewable energy statistics\#Primary production (Acc. 20 April 2016, data extracted in Maj 2015).

Eurostat, 2015b. Share of renewables in gross final energy consumption, 2013 and 2020 (\%), URL: $\quad$ http://ec.europa.eu/eurostat/statisticsexplained/index.php/File:Share of renewables in gross final energy consumptio n, 2013 and 2020 (\%25) YB15.png (Acc. 5 April 2016, original file created in June 2015). 
Fischer, C., 2008. Who uses innovative energy technologies, when and why? The case of fuel cell MicroCHP in households. International Journal of Environmental Technology and Management 9, 236-258.

Jacobsson, S., Bergek, A., 2011. Innovation system analyses and sustainability transitions: Contributions and suggestions for research. Environmental Innovation and Societal Transitions 1, 41-57.

Jensen, R.A., 1982. Adoption and Diffusion of an Innovation of Uncertain Profitability. Journal of Economic Theory 27, 182-193.

Kaplowitz, M.D., Hadlock, T.D., Levine, R., 2004. A Comparison of Web and Mail Survey Response Rates. Public Opinion Quarterly 68, 94-101.

Karakaya, E., Hidalgo, A., Nuur, C., 2015. Motivators for adoption of photovoltaic systems at grid parity: A case study from Southern Germany. Renewable and Sustainable Energy Reviews 43, 1090-1098.

Korcaj, L., Hahnel, U.J.J., Spada, H., 2015. Intentions to adopt photovoltaic systems depend on homeowners' expected personal gains and behavior of peers. Renewable Energy 75, 407-415.

Lillemo, S.C., Alfnes, F., Halvorsen, B., Wik, M., 2013. Households' heating investments: The effect of motives and attitudes on choice of equipment. Biomass and Bioenergy 57, 4-12.

Lindenberg, S., Steg, L., 2007. Normative, Gain and Hedonic Goal Frames Guiding Environmental Behavior. Journal of Social Issues 63, 117-137.

Linton, J.D., 2002. Implementation research: state of the art and future directions. Technovation 22, 65-79.

Mbzibain, A., Hocking, T.J., Tate, G., Ali, S., 2013. Renewable enterprises on UK farms: Assessing levels of uptake, motivations and constraints to widespread adoption. Biomass and Bioenergy 49, 28-37.

Michelsen, C.C., Madlener, R., 2013. Motivational factors influencing the homeowners' decisions between residential heating systems: An empirical analysis for Germany. Energy Policy 57, 221-233.

Mignon, I., 2016. Intermediary-user collaboration during the innovation implementation process. accepted for publication in TASM.

Mignon, I., Bergek, A., 2016. Investments in renewable electricity production: The importance of policy revisited. Renewable Energy 88, 307-316.

Noppers, E.H., Keizer, K., Bolderdijk, J.W., Steg, L., 2014. The adoption of sustainable innovations: Driven by symbolic and environmental motives. Global Environmental Change 25, 52-62.

Nygrén, N.A., Kontio, P., Lyytimäki, J., Varho, V., Tapio, P., 2015. Early adopters boosting the diffusion of sustainable small-scale energy solutions. Renewable and Sustainable Energy Reviews 46, 79-87.

Palm, J., Tengvard, M., 2011. Motives for and barriers to household adoption of small-scale production of electricity: examples from Sweden. Sustainability: Science, Practice, \& Policy 7, 6-15.

Rogers, E.M., 1983. Diffusion of Innovations, 3rd ed. The Free Press, New York.

Schelly, C., 2014. Residential solar electricity adoption: What motivates, and what matters? A case study of early adopters. Energy Research \& Social Science 2, 183191.

Sidiras, D.K., Koukios, E.G., 2004. Solar systems diffusion in local markets. Energy Policy 32, 2007-2018. 
Stern, P.C., 2000. New Environmental Theories: Toward a Coherent Theory of Environmentally Significant Behavior. Journal of Social Issues 56, 407-424.

Swedish Energy Agency, Norwegian Water Resources and Energy Directorate (NVE), 2016. En svensk-norsk elcertifikatsmarknad. NVEs hustrykkeri, Oslo/Stockholm.

Tate, G., Mbzibain, A., Ali, S., 2012. A comparison of the drivers influencing farmers' adoption of enterprises associated with renewable energy. Energy Policy 49, 400409.

Tidd, J., 2010. From Models to the Management of Diffusion, in: Tidd, J. (Ed.), Gaining Momentum: Managing the Diffusion of Innovations. Imperial College Press, London, pp. 3-46.

trend:research, 2013. Definition und Marktanalyse von Bürgerenergie in Deutschland. Institut für Trend- und Marktforschung, Bremen.

Walekhwa, P.N., Mugisha, J., Drake, L., 2009. Biogas energy from family-sized digesters in Uganda: Critical factors and policy implications. Energy Policy 37, 2754-2762.

Warren, P., 2010. Uptake of Micro-generation among Small Organisations in the Camden Climate Change Alliance, Department of Geography, Faculty of Social Sciences and Health. Durham University, Durham.

Vasseur, V., Kemp, R., 2015. The adoption of PV in the Netherlands: A statistical analysis of adoption factors. Renewable and Sustainable Energy Reviews 41, 483-494.

Wüstenhagen, R., Menichetti, E., 2012. Strategic choices for renewable energy investment: Conceptual framework and opportunities for further research. Energy Policy 40, 110.

Yin, R.K., 1984. Case study research: Designs and Methods. Sage Publications, Beverly Hills, CA. 